Review Article

\section{Avermectins: The promising solution to control plant parasitic nematodes}

\author{
Mohamed S Khalil1* and Dalia M Darwesh² \\ ${ }^{1}$ Central Agricultural Pesticides Laboratory, Agricultural Research Center, El-Sabaheya, Alexandria, Egypt \\ ${ }^{2}$ The Egyptian ministry of Agriculture, Damanhur, Egypt
}

\section{Abstract}

Abamectin and emamectin are members of avermectin family which categorized as very effective but in the same time are toxic naturally. Most of products in this family are utilized as pharmaceuticals in both humans \& animals and for crop protection. Despite avermectins are having complex chemical structures, but they are produced via synthesis in large scales for commercial use. Plant parasitic nematodes (PPNs) cause severe damages in all parts of their host plants, in addition to yield losses. The available strategies to control PPN include use of insecticides/ nematicides but these have proved detrimental to environment and human health. Therefore, this scenario gave an opportunity for the utilization of avermectins (abamectin and emamectin) to control plant parasitic nematodes because of their chemical and biological properties, as well as relative safety. Avermectins have short half-lives and their residues can be eliminated easily through different food processing methods. Both abamectin and emamectin were very effective nematicides which proved capability of reducing PPNs significantly in various crops.

\section{More Information}

*Address for Correspondence: Mohamed S Khalil, Central Agricultural Pesticides Laboratory, Agricultural Research Center, El-Sabaheya, Alexandria, Egypt, Tel: 201009297847; Email: melonema@gmail.com

\section{Submitted: 06 September 2019}

Approved: 12 September 2019

Published: 13 September 2019

How to cite this article: Khalil MS, Darwesh DM. Avermectins: The promising solution to control plant parasitic nematodes. J Plant Sci Phytopathol. 2019; 3: 081-085.

DOI: dx.doi.org/10.29328/journal.jpsp.1001036

Copyright: @ 2019 Khalil MS, et al. This is an open access article distributed under the Creative Commons Attribution License, which permits unrestricted use, distribution, and reproduction in any medium, provided the original work is properly cited

Check for updates

\section{Introduction}

Plant parasitic nematodes (PPNs) considered a threat to crops production and are responsible for about US $\$ 173$ billion annual losses in agriculture world [1]. Sometimes, PPNs are co-operating with other plant pathogens such as bacteria and fungi and cause complex diseases. Nematodes can damage all parts of their host plants, although according to their life style, individual species target the roots, stems, leaves, flowers, or seeds. There are about $31 \%$ of known species of nematodes are parasites of vertebrates [2], while $16 \%$ are parasites of plants, mostly soil-borne root pathogens [3]. Approximately $2.4 \%$ species of those parasites on plants are responsible for economically important phytoparasites of crops.

Globally, farmers are still depending on chemical nematicides to control PPNs, because of their effectiveness, but the environmental aspects of these synthetic pesticides was drastically devastating [4]. Avermectins are one of new alternatives which proved its activity towards different genera of plant parasitic nematodes [5-10]. Avermectins were discovered in 1976 by scientists at Merck \& Co. Inc. obtained from isolate by the Kitasato Institute from soil samples collected at Kawana, Ito city, Shizuoka Prefecture, Japan [11]. Avermectins are sub-class of natural products that consisting of a large macrocyclic lactone ring which produced from metabolites of Gram-positive bacterium, Streptomyces avermectinius [12].
The residue of avermectins is rapidly decomposed under sunlight, resulting in a relatively low toxicity to beneficial insects [13]. They are rapidly photodegraded in water with a half-life $(\mathrm{t} 1 / 2)$ of approximately 0.5 days or less in summer. Emamectin benzoate, a novel insecticide with translaminar movement in plant leaf tissue. Emamectin has improved thermal stability, greater water solubility and a broader spectrum of insecticidal activity than abamectin [14]. The half-life of emamectin benzoate may reach 7 days in water, but may reduce to one day if the water contained a natural photosensitizer such as humic acid. However, the half-life of emamectin benzoate under sunlight in water may take 22 days. The half-life of abamectin on water surface was only 4 to $6 \mathrm{~h}$ [14]. Therefore, this review aimed to clarified the importance of avermectin group especially; abamectin and emamectin to use as a new nematicides which are environmentally safe than other synthetic nematicides.

\section{Abamectin}

Abamectin is belonging to the sub-group: Avermectins that follow the macrocyclic lactones group. Avermectins have been obtained from Gram-positive bacterium, Streptomyces avermitilis [15]. Newly, the name of bacterium species was changed to Streptomyces avermectinius [12].

Avermectins are consisting of eight components which divided to four major components as $\mathrm{A}_{\mathrm{a}^{\prime}} \mathrm{A} 2_{\mathrm{a}^{\prime}} \mathrm{B} 1_{\mathrm{a}}$ and $\mathrm{B} 2 \mathrm{a}_{\mathrm{a}}$ 
and four minor components as $\mathrm{A} 1_{\mathrm{b}}, \mathrm{A} 2_{\mathrm{b}}, \mathrm{B} 1_{\mathrm{b}}$ and $\mathrm{B} 2_{\mathrm{b}}$ [16]. The component $(\mathrm{A})$ means that there is a methoxy group at the $\mathrm{C}_{5}$ - position and component (B) means that there is a hydroxy group at the $\mathrm{C}_{5}$ - position. While component (a) means that there is a secondary butyl side chain at the $\mathrm{C}_{25}$ position and component (b) means that there is an isopropyl substituent at the $\mathrm{C}_{25}$ - position. Also, component (1) means that there is double bond between $\mathrm{C}_{22}$ and $\mathrm{C}_{23}$ - position, whereas component (2) means that there is a single bond with a hydroxy group at the $\mathrm{C}_{23}$ - position. Abamectin (avermectin $\mathrm{B} 1$ ) is a blend of avermectin $\mathrm{B} 1_{\mathrm{a}}(\geq 80 \%)$ and $\mathrm{B} 1_{\mathrm{b}}(\leq 20 \%)$ as mentioned by [15]. Both components $\mathrm{B}_{\mathrm{a}}$ and $\mathrm{Bl}_{\mathrm{b}}$ of abamectin almost have the same biological and toxicological properties [16].

Recently, a new member of avermectins family was registered in china as a patent under number (2012105478044). This new member was Abamectin B2 which produced by Hebei Xingbai Agricultural Technology Co., Ltd., China. This compound was registered to manage the root-knot nematodes in different crops such as tomato, cucumber, celery, watermelon, peanut, soybean, banana, coffee and Chinese herbal medicine plants and applied at little amounts. Abamectin B2 which contains a mixture of $\mathrm{B}_{2 \mathrm{a}}$ and $\mathrm{B}_{2 \mathrm{~b}}$ was registered under trade name Xing-Bai ${ }^{\circledR}(5.0 \% \mathrm{EC})$.

\section{The environmental aspects of abamectin}

The toxicity of abamectin is low towards non-target organisms. This aspect nominated abamectin to join into the integrated pest management (IPM) programs, as well as proved its safety to human beings and environmental components [16].

Avermectins have relatively shorter residual activities. The stability of abamectin is moderate in environment. The half-life of abamectin under field conditions was about $31 \pm 6$ days, while the half-life was ranged between 20 and 47 days in soils with 5 - $9 \mathrm{pH}$. The photo-degradation occurs in thin films (6 hours) and water (12 hours), while it was 21 hours in soil [17]. Despite its rapid decomposition in various systems, abamectin still provides a relatively long residual activity against target pests in field conditions due to its translaminar activity [18].

The systemic activity of abamectin is limited and the water solubility is very low because of its binding with soil particles tightly, resulting in poor movement of the product through the soil profile $[16,19,20]$.

The residues of abamectin are very low in treated plants because of it is highly degraded readily by soil microorganisms. Moreover, the most avermectin degradation products have been reported to pose 1-3 times less toxicity than the parent compound. The temperature coefficient of abamectin is positive which mean that the toxicity increased with the increment of temperature till $37^{\circ} \mathrm{C}$ [17].

\section{The efficacy of abamectin on plant parasitic nematodes}

The avermectin B1 (Abamectin) proved its ability to manage different pests as an acaricide [16,21], insecticides [22], nematicide [10,23] and Molluscicide [24-26]. Meanwhile, abamectin was applied in many different methods such as soil treatment, seed treatment, injection in to plant stem and seedling root dip (Table 1) (Figure 1).

\section{Emamectin benzoate}

Emamectin benzoate is a novel avermectin derivative which belongs to the macrocyclic lactones family. Emamectin benzoate was developed as a pesticide by Merck and Company and was classified as a second generation of avermectins which is a derivative of abamectin. Emamectin benzoate is a biological insecticide contains a mixture of the benzoic acid salt of two structurally complex heterocyclic compounds which were emamectin $\mathrm{B} 1_{\mathrm{a}}(>90 \%)$ and emamectin $\mathrm{B} 1_{\mathrm{b}}(<$

\begin{tabular}{|c|c|c|c|c|c|c|c|c|}
\hline \multirow{2}{*}{ Compounds } & \multirow{2}{*}{ Nematodes' genera } & \multirow{2}{*}{ Crops } & \multirow{2}{*}{$\begin{array}{l}\text { Application } \\
\text { methods }\end{array}$} & \multicolumn{4}{|c|}{ Reduction parameters (\%) } & \multirow{2}{*}{ Authors } \\
\hline & & & & Population & Galls & Egg masses & Eggs & \\
\hline $\begin{array}{r}\text { Vertemic }^{\circledR} \\
(1.8 \% \mathrm{EC})\end{array}$ & Meloidogyne incognita & Rapeseed & Soil Application & $94.2 \%$ & $61.5 \%$ & $92.5 \%$ & --- & Korayem, et al. [42] \\
\hline $\begin{array}{c}\text { Abamectin } \\
(1.8 \% \mathrm{EC})\end{array}$ & Meloidogyne incognita & Egg plants & Soil Application & -- & $61.77 \%$ & $78.82 \%$ & -- & Shahid, et al. [43] \\
\hline \multirow{3}{*}{ Abamectin } & Pratylenchus zeae & Maize & \multirow{3}{*}{ seed treatment } & $80 \%$ & --- & --- & --- & \multirow{3}{*}{ Cabrera, et al. [6] } \\
\hline & Heterodera schachtii & Sugar beets & & $60 \%$ & -- & -+- & -+- & \\
\hline & Meloidogyne incognita & Cotton & & --- & $80 \%$ & 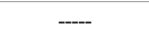 & ---- & \\
\hline $\begin{array}{r}\text { Vertemic }^{\circledR} \\
(1.8 \% \mathrm{EC})\end{array}$ & Meloidogyne incognita & Tomato & Soil Application & $74.0 \%$ & $60.7 \%$ & -- & --- & Khalil, [44] \\
\hline \multirow{2}{*}{$\begin{array}{l}\text { Vertemic }^{\circledR} \\
(1.8 \% \mathrm{EC})\end{array}$} & Meloidogyne incognita & \multirow{2}{*}{ Cabbage } & \multirow{2}{*}{ Soil Application } & -- & $40 \%$ to $88 \%$ & $58 \%$ to $98 \%$ & & \multirow{2}{*}{ Ibrahim, et al. [7] } \\
\hline & Heterodera schachtii & & & $68 \%$ to $92 \%$ & --- & -- & -- & \\
\hline $\begin{array}{l}\text { Vertemic }^{\circledR} \\
(1.8 \% \text { EC) }\end{array}$ & Meloidogyne incognita & Tomato & Soil Application & $61.3 \%$ & $68.0 \%$ & $41.7 \%$ & --- & $\begin{array}{l}\text { Youssef and } \\
\text { Lashein, [45] }\end{array}$ \\
\hline Tervigo $^{\circledR}(2 \%$ SC) & Meloidogyne incognita & Tomato & Soil Application & $75.34 \%$ & $66.69 \%$ & $66.31 \%$ & $16.34 \%$ & Saad, et al. [46] \\
\hline Tervigo $^{\circledR}(2 \% \mathrm{SC})$ & $\begin{array}{c}\text { Tylenchulus } \\
\text { semipenetrans }\end{array}$ & orange trees & Soil Application & $78 \%$ to $87 \%$ & -- & -- & -- & El-Tanany, et al. [9] \\
\hline $\begin{array}{r}\text { Tervigo }^{\circledR} \\
(2 \% \mathrm{SC})\end{array}$ & Meloidogyne incognita & Tomato & Soil Application & $86 \%$ to $91 \%$ & $67 \%$ to $71 \%$ & $70 \%$ to $78 \%$ & $40 \%$ to $63 \%$ & Radwan, et al. [23] \\
\hline $\begin{array}{r}\text { Tervigo }^{\circledR} \\
(2 \% \text { SC) }\end{array}$ & Meloidogyne incognita & Tomato & Soil Application & $78.88 \%$ to $81.07 \%$ & $\begin{array}{c}71.64 \% \text { to } \\
72.48 \%\end{array}$ & - & --- & $\begin{array}{c}\text { Khalil and Alqadasi, } \\
{[10]}\end{array}$ \\
\hline
\end{tabular}




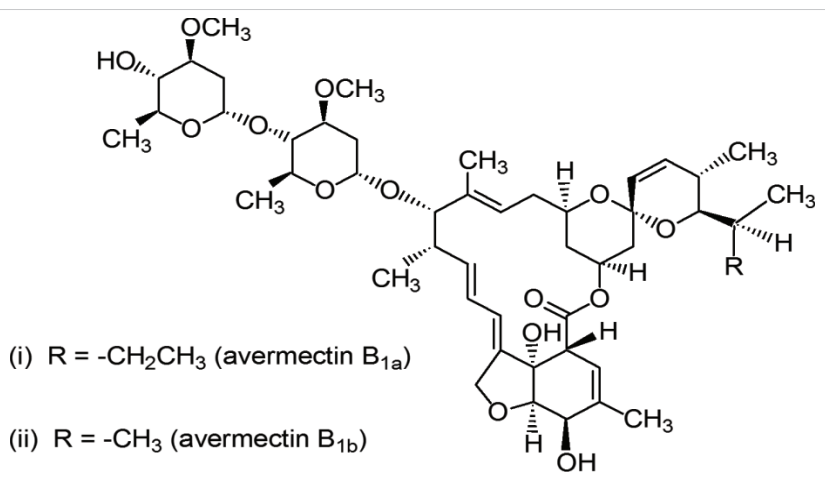

Figure 1: The chemical structure of abamectin (avermectin $\mathrm{B} 1_{\mathrm{a}}$ and $\mathrm{B} 1_{\mathrm{b}}$ ).

10\%). The only differs between emamectin B1 \& emamectin $\mathrm{B} 1_{\mathrm{b}}$ is the presence of an additional methylene unit on the side chain at C-25 [27].

However, emamectin benzoate is consisting of a 16-membered ring macrolide and a di-saccharide via substitution of an epi-methylamino (-NHCH3) group for a hydroxyl $(-\mathrm{OH})$ group at the 4"-position on the di-saccharide. The limited potentiality of abamectin towards the most of Lepidoptera pushes the scientists to focus and try many prompts to get an alternative compound (s). According to these prompts they discovered of 4"-epi-methylamino-4"-deoxyavermectin B1 ${ }_{\text {a\&b }}$ (emamectin) in 1984. Emamectin was derived from abamectin via a five step synthesis [28].

Many investigations clarified that emamectin benzoate were applied as soil drench to control underground nematodes $[23,29,30]$ and as injection in to the plant trunk/stem [31].

\section{Environmental aspects of emamectin benzoate}

Because of that emamectin was derived from soil microbes it offers a promising solution to inhibit environmental pollution and crop losses due to the invasion of pests and diseases. The diversity in structure, activity, biodegradability and the eco-friendly properties make these proposed microbial derivatives, agricultural active agents of the future generation [32]. Also, emamectin benzoate is safe towards non target organisms, as well as it has low residue and environmental pollution [33-36]. The both components of emamectin have similar structure; thus, their physicochemical properties, fate, and toxicity profiles are almost to be similar.

Emamectin benzoate showed thermal stability and greater water solubility, which then resulted in a broader spectrum of insecticidal activity than abamectin [31]. The half-life of emamectin benzoate in water may reach to 7 days, but would be reduced to as short as one day if the water contained a natural photosensitizer such as humic acid. Meanwhile, the stability of emamectin benzoate's characteristics is depending on pH levels. For example, the solubility of emamectin in water reach to $320 \mathrm{mg} / \mathrm{L}$ at $\mathrm{pH} 5,93 \mathrm{mg} / \mathrm{L}$ at $\mathrm{pH} 7$, and $0.1 \mathrm{mg} / \mathrm{L}$ at $\mathrm{pH}$ 9. Similarly, its $\log \mathrm{K}_{\text {ow }}$ is 5.0 at pH 7 and 5.9 at pH 9 .

Also, the photo-degradation of emamectin benzoate in soils may reach to 22 days under sunlight. While in darkness the degradation process of emamectin is stable in soils $[27,37]$. Previous studies revealed that photo-degradation may produces many byproducts under UV light [27,38-40]. The vapor pressure and Henry's constant of emamectin benzoate are low, therefore these suggest that volatility from soil and water will be low.

Table 2: The effect of emamectin benzoate on various genera of plant parasitic nematodes.

\begin{tabular}{|c|c|c|c|c|c|c|c|c|}
\hline \multirow{2}{*}{ Compounds } & \multirow{2}{*}{ Nematodes' genera } & \multirow{2}{*}{ Crops } & \multirow{2}{*}{$\begin{array}{l}\text { Application } \\
\text { methods }\end{array}$} & \multicolumn{4}{|c|}{ Reduced parameters (\%) } & \multirow{2}{*}{ Author (s) } \\
\hline & & & & Population & Galls & Egg masses & Eggs & \\
\hline $\begin{array}{c}\text { Emamectin } \\
\text { benzoate } \\
(5 \% \text { SG) }\end{array}$ & Meloidogyne javanica & Banana & Stem injection & --- & $\begin{array}{l}46.67 \% \text { to } \\
86.67 \%\end{array}$ & - & --- & $\begin{array}{l}\text { Jansson and } \\
\text { Rabatin, [5] }\end{array}$ \\
\hline \multirow{2}{*}{$\begin{array}{l}\text { Emamectin } \\
\text { benzoate } \\
(5 \% \text { SG) }\end{array}$} & \multirow[b]{2}{*}{ Radopholus similis } & \multirow[b]{2}{*}{ Banana } & Stem injection & $64.29 \%$ to $76.62 \%$ & \multirow{2}{*}{-} & \multirow[b]{2}{*}{-} & \multirow[b]{2}{*}{--} & \multirow{2}{*}{$\begin{array}{l}\text { Jansson and } \\
\text { Rabatin, [5] }\end{array}$} \\
\hline & & & Root dip & $81.73 \%$ & & & & \\
\hline $\begin{array}{l}\text { Emamectin } \\
\text { benzoate }\end{array}$ & Meloidogyne incognita & Tomato & Soil Application & -- & - & $\begin{array}{l}49.50 \% \text { to } \\
58.10 \%\end{array}$ & $\begin{array}{l}22.90 \% \text { to } \\
26.80 \%\end{array}$ & $\begin{array}{c}\text { Rehman, et al. } \\
{[47]}\end{array}$ \\
\hline $\begin{array}{l}\text { Emamectin } \\
\text { benzoate }\end{array}$ & Meloidogyne spp. & Egg plants & Soil Application & -- & $43.75 \%$ & $56.41 \%$ & - & Shahid, et al. [43] \\
\hline $\begin{array}{l}\text { Emamectin } \\
\text { benzoate }\end{array}$ & $\begin{array}{l}\text { Bursaphelenchus } \\
\text { xylophilus }\end{array}$ & Pinewood trees & Soil Application & $98.03 \%$ & --- & --- & $85.61 \%$ & $\mathrm{Bi}$, et al. [8] \\
\hline $\begin{array}{l}\text { Emamectin } \\
\text { benzoate }\end{array}$ & Meloidogyne incognita & Tomato & Soil Application & ---- & $\begin{array}{c}73.4 \% \text { to } \\
87.7 \%\end{array}$ & --- & --- & Cheng, et al. [48] \\
\hline $\begin{array}{l}\text { Emamectin } \\
\text { benzoate }\end{array}$ & Meloidogyne incognita & Egg Plant & Soil Application & $46.8 \%$ ( females) & --- & - & - & Atif, et al. [29] \\
\hline $\begin{array}{c}\text { Emamectin } \\
\text { benzoate } \\
\left(\text { Proclaim }^{\circledR} 5 \% \text { WG }\right)\end{array}$ & Meloidogyne incognita & Tomato & Soil Application & $91.81 \%$ & $71.65 \%$ & $76.28 \%$ & $61.71 \%$ & Khalil, [30] \\
\hline $\begin{array}{c}\text { Emamectin } \\
\text { benzoate } \\
\left.\text { (Proclaim }^{\circledR} 5 \% \text { WG }\right)\end{array}$ & Meloidogyne incognita & Tomato & Soil Application & $60 \%$ to $63 \%$ & $75 \%$ to $77 \%$ & $60 \%$ to $62 \%$ & $90 \%$ to $93 \%$ & $\begin{array}{c}\text { Radwan, et al. } \\
{[23]}\end{array}$ \\
\hline
\end{tabular}




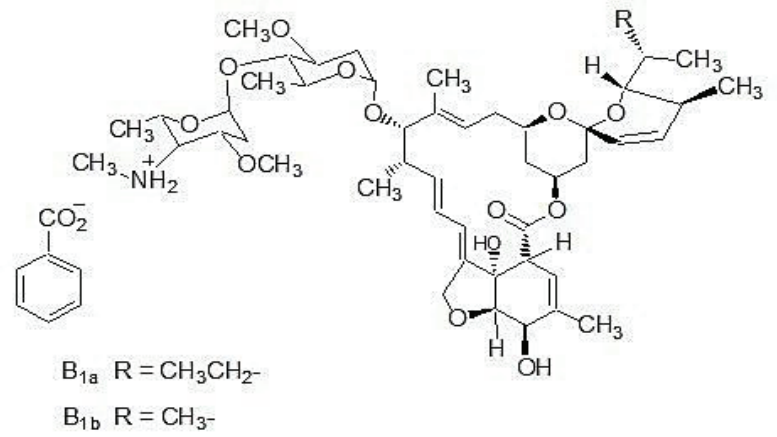

Figure 2: The chemical structure of emamectin benzoate.

The effect of emamectin on plant parasitic nematodes

Emamectin benzoate is a novel semi-synthetic derivative antibiotic which has a wide spectrum activity against insects $[33,34]$. However, certain reports indicated that emamectin benzoate was effective against different genera of plant parasitic nematodes according to the received information from [41], [8,12] but emamectin was less effective than abamectin. Until now there is no registered compound of emamectin benzoate to manage PPNs. The obtained data in the following (Table 2) showed the impact of emamectin benzoate on different plant parasitic nematodes genera in various crops (Figure 2).

\section{References}

1. Elling AA. Major emerging problems with minor Meloidogyne species. Phytopathology. 2013; 103: 1092-1102.

PubMed: https://www.ncbi.nlm.nih.gov/pubmed/23777404

2. Hugot JP, Baujard P, Morand S. Biodiversity in helminths and nematodes as a field of study: an overview. Nematology. 2001; 3:199-208.

3. Nicol JM, Turner SJ, Coyne DL, den Nijs L, Hockand S, et al. Current nematode threats to world agriculture. In: Jones J, Gheysen G, Fenoll C (eds) Genomics and molecular genetics of plant-nematode interactions. Springer Dordrecht. 2011; 21-43.

4. Khalil MS, Darwesh DM. Some integrated practices to manage rootknot nematodes on tomatoes: A Mini Review. Innovative Techniques in Agriculture. 2018; 3: 618-625.

5. Jansson RK, Rabatin S. Potential of foliar, dip, and injection applications of avermectins for control of plant-parasitic nematodes. J Nematol. 1998; 30: 65-75.

PubMed: https://www.ncbi.nlm.nih.gov/pmc/articles/PMC2620280/

6. Cabrera JA, Kiewnick S, Grimm C, Dababat AA, Sikora RA. Efficacy of abamectin seed treatment on Pratylenchus zeae, Meloidogyne incognita and Heterodera schachtii. J Plant Dis Prot. 2009; 116: 124-128.

7. Ibrahim IKA, Basyony ABA, Handoo ZA, Chitwood DJ. Pathogenicity and control of Heterodera schacht and Meloidogyne spp. on some cruciferous plant cultivars. Inte J Nematol. 2013; 23: 73-81.

8. Bi Z, Gong Y, Huang X, Yu H, Bai L, et al. Efficacy of Four Nematicides against the Reproduction and Development of Pinewood Nematode, Bursaphelenchus xylophilus. 2015; J Nematol. 47: 126-132.

PubMed: https://www.ncbi.nlm.nih.gov/pubmed/26170474

9. El-Tanany MM, El-Shahaat MS, Khalil MS. Efficacy of three bio-pesticides and oxamyl against citrus nematode (Tylenchulus semipenetrans) and on productivity of Washington navel orange trees. Egyptian J Horticulture. 2018; 45: 275-287.
10. Khalil MS, Alqadasi AAA. Potential of non-fumigant nematicides at different formulations against southern root-knot nematode (Meloidogyne incognita) on tomato plants. Int J Phytopathol. 2019; 8: 23-28.

11. Fisher MH. Recent advances in avermectin research. Pure Appl Chem. 1990; 62: 1231-1240.

12. Khalil MS, Abd El-Naby SSI. The integration efficacy of formulated abamectin, Bacillus thuringiensis and Bacillus subtilis for managing Meloidogyne incognita (Kofoid and White) Chitwood on tomatoes. J Biopesticides. 2018; 11: 146-153.

13. Feely WF, Crouch LS, Arison BH, VandenHeuvel WJA, Colwell LF, et al. Photodegradation of 4 "-(epi-methylamino)-4"-deoxyavermectin B1a thin films on glass. J Agric Food Chem. 1992; 40: 691-696.

14. Zhu JY, He M, Gao W, Zhou J, Hu J, et al. Photodegradation of emamectin benzoate and its influence on efficacy against the rice stem borer, Chilo suppressalis. Crop Protection. 2011; 30: 1356-1362.

15. Pitterna T, Cassayre J, Hüter OF, Jung PM, Maienfisch $P$, et al. New ventures in the chemistry of avermectins. Bioorg Med Chem. 2009; 17: 4085-4095.

PubMed: https://www.ncbi.nlm.nih.gov/pubmed/19168364

16. Khalil MS. Abamectin and azadirachtin as eco-friendly promising biorational tools in integrated nematodes management programs. $J$ Plant Pathol Microb. 2013; 4: 174.

17. Boina DR, Onagbola EO, Salyani M, Stelinski LL. Influence of posttreatment temperature on the toxicity of insecticides against Diaphorina citri (Hemiptera: Psyllidae). J Econ Entomol. 2009; 102: 685-691.

PubMed: https://www.ncbi.nlm.nih.gov/pubmed/19449650

18. Wright DJ, Loy A, Green ASJ, Daybas RA. The translaminar activity of abamectin (MK-936) against mites and aphids. Meded Fac. Land bouwwet. Rijks Univ Gent. 1985; 50: 633e637.

19. Bull DL, Ivie W, MacDonnel JG, Gruber VF, Ku CC, et al. Fate of avermectin B1a in soil and plants. J Agric Food Chem. 1984; 32: 94-102.

20. Chukwudebe AC, Feely WF, Burnett TJ, Crouch LS, Wislocki PG. Uptake of emamectin benzoate residues from soil by rotational crops. J Agric Food Chem. 1996; 44: 4015-4021.

21. Dybas RA, Green ASJ. Avermectins: their chemistry and pesticidal activity. British Crop Protection Conference. Pest and Diseases, 1984 9B- 3: 947-954.

22. Lumaret JP, Errouissi F, Floate K, Römbke J, Wardhaugh K. A Review on the Toxicity and Non-Target Effects of Macrocyclic Lactones in Terrestrial and Aquatic Environments. Current Pharmaceutical Biotechnology, 2012; 13: 1004-1060.

23. Radwan MA, Saad ASA, Mesbah HA, Ibrahim HS, Khalil MS. Investigating the In vitro and In vivo nematicidal performance of structurally related macrolides against the root-knot nematode, Meloidogyne incognita. Hellenic Plant Protection Journal. 2019; 12: 24-37.

24. Abdallah EAM, Abdelgalil GM, Kassem FA, Asran AA, Abou-Elnasser HS. Comparative molluscicidal activity of abamectin and methomyl against Eobania vermiculata (Muller) and Theba pisana (Muller). J Plant Prot and Path Mansoura Univ. 2015; 6: 1671-1683.

25. Abdelgalil GM. Molluscicidal activity and biochemical studies of some pesticides against terrestrial snails. Ph. D. Thesis of Agric. Faculty. Alex. Univ. Egypt. 2016.

26. Abdelgalil GM, Abou-Elnasr HS, Khalil MS, Abouhamer MS, Osman AM et al. Molluscicidal toxicity of abamectin against Eobania vermiculata and Theba pisana in vitro and the estimation of GABA-Transaminase activity by HPLC. J Biopesticides. 2018; 11:161-168. 
27. Mushtaq M, Chukwudebe AC, Wrzesinski C, Allen LRS, Luffer-Atlas D, et al. Photodegradation of emamectin benzoate in aqueous solution. $\mathrm{J}$ Agric Food Chem. 1998; 46: 1181-1191.

28. Cvetovich RJ, Kelly DH, Di Michele LM, Shuman RF, Grabowski EJJ. Synthesis of 4"- epi-amino-4"-deoxyavermectins B1. J Organic Chemistry. 1994; 59: 7704-7708.

29. Aatif HM, Javed N, Ullah MI, Lali SP, Iqbal Z, et al. Biological management of Meloidogyne incognita using entomopathogenic bacterial cell suspensions with other bioproducts in egg plant. Pak J Zool. 2016; 48 $887-890$

30. Khalil MS. Evaluation of some management practices against root knot nematode in tomato. PhD. thesis, Alexandria University, Alexandria, Egypt, 2018; 174.

31. Jansson RK, Dybas RA. Avermectins: biochemical mode of action, biological activity and agricultural importance, pp. 153e170. In: Ishaaya, I., Degheele, D. (Eds.), Insecticides with Novel Modes of Actiondmechanisms and Application. Springer, Berlin, Heidelberg, New York. 1998.

32. Birtle AJ, Crops AE, Wright DJ. Biological effects of avermectins on nematodes. XVIth international Symposium of Nematology. St. Andrews, (Abstr.). 1982; 75.

33. Zhou L, Luo F, Zhang $X$, Jiang $Y$, Lou Z, et al. Dissipation, transfer and safety evaluation of emamectin benzoate in tea. Food Chemistry. 2016 202: 199-204.

PubMed: https://www.ncbi.nlm.nih.gov/pubmed/26920285

34. Han PJ, Fan RJ, Feng YT, Du EQ, Zhao RH. Control efficacy of $2.2 \%$ emamectin benzoate ME against rice stem borer (Chilo suppressalis). J Southern Agri. 2011; 42: 403-405.

35. Shang Q, Y Shi, Y Zhang, TZheng, H Shi. Pesticide conjugated polyacrylate nanoparticles: novel opportunities for improving the photostability of emamectin benzoate. Polymers for Advanced Technologies. 2013; 24: 137-143.

36. Guo M, Zhang W, Ding G, Guo D, Zhu J, etal. Preparation and characterization of enzyme-responsive emamectin benzoate microcapsules based on a copolymer matrix of silica-epi chlorohydrin carboxy methylcellulose. RSC Advances. 2015; 5: 93170- 93179.

37. Mushtaq M, Feely WF, Syintsakos LR, Wislocki PG. Immobility of emamectin benzoate in soils. J Agric Food Chem. 1996: 44: 940-944.

38. Feely WF, Crouch LS, Arison BH, VandenHeuvel WJA, Colwell LF, et al. Photodegradation of 400-(epi-methylamino)-400-deoxyavermectin
B1a thin films on glass. J Agric Food Chem. 1992; 40: 691- 696.

39. Wrzesinski CL, Arison BH, Smith J, Zink DL, VandenHeuvel WJA Isolation and identification of residues of 400-(epi-methylamino)-400deoxyavermectin B1a benzoate from the surface of cabbage. J Agric Food Chem. 1996; 44: 304-312.

40. Crouch LS, Feely WF. Fate of [14C] Emamectin benzoate in head lettuce. J Agric Food Chem. 1995; 43: 3075-3087.

41. Abbas W, Anwar SA, Zia A, Javed N. Response of four tomato cultivars to Meloidogyne incognita infection and its chemical management. Pak J Nematol. 2008; 26: 37-43.

42. Korayem AM, Mahmoud MAY, Moawad MMM. Effect of chitin and abamectin on Meloidogine incognita infesting rape seed. J Plant Protection Res. 2008; 48: 365-370.

43. Shahid M, Rehman AU, Khan SH, Mahmood K, Khan AU. Management of root-knot nematode infecting brinjal by biopesticides, chemicals, organic amendments and bio-control agent. Pak J Nematol. 2009; 27: 159-166.

44. Khalil MS. A comparison study with alternative biorational agents to suppress the root-knot nematode populations and gall-formation in tomato plants. Inte J Nematol. 2012; 22: 112-116.

45. Youssef MMA, Lashein AMS. Effect of some commercial biofertilizers and a biocide on root knot nematode, Meloidogyne incognita infesting date palm in a newly reclaimed soil in Egypt. Middle East J App Sci. 2015; 5: 143-147.

46. Saad ASA, Radwan MA, Mesbah HA, Ibrahim HS, Khalil MS. Evaluation of some non-fumigant nematicides and the biocide avermectin for managing Meloidogyne incognita in tomatoes. Pakistan Journal of Nematology. 2017; 35: 85-92.

47. Rehman AU, Javed N, Ahmad R, Shahid M. Integration of bio-products and Pasteuria penetrans for the management of root-knot Nematode over three crop cycles of tomato. Pak J Nematol. 2009; 27: 325-336.

48. Cheng $X$, Liu X, Wang $H$, Ji X, Wang $K$, et al. Effect of emamectin benzoate on root-knot nematodes and tomato yield. PLoS One 2015; 10: e0141235.

PubMed: https://www.ncbi.nlm.nih.gov/pmc/articles/PMC4624971/ 